\title{
CORRESPONDENCE IN THE MESSENGER: IDENTIFYING THE AUTHOR BY TEXT IN THE CONTEXT OF THE TRANSFORMATION OF INDIVIDUALIZING FEATURES
}

\author{
Anastasiya V. Gromova \\ Forensic Centre of the Ministry of Internal Affairs of the Russian Federation, Moscow, Russia
}

\begin{abstract}
The article discusses the texts of Internet-based communication and correspondence in a messenger, the attention is paid to description of similarities and differences between oral and written dialogical speech. The problems of neutralizing speech features in the format of Internet-based communication and the transformation of attributes, which provide individual characteristic of the author demonstrated whilst exchanging messages in a messenger. It has been proposed to define the form of speech, typical of correspondence in the messenger, as dialogical written (printed) speech, with reference to it as to the product of intellectual activity in combination with the form of its implementation, taking into account the factor of the author's usage of technical means for typing. The author represents the approaches to identifying significant speech characteristics, which are demonstrated by the addresser in written correspondence in the messenger; these approaches are often analyzed in the process of authorship identification tests. The possibility of revealing a complex of author's individualizing features is proved. This paper emphasizes the importance of studying the signs of the graphic and communicative levels of the analysis of dialogical texts, provides the examples of implementation of such signs. In this article the relevance of combining linguistic and quantitative methods of analysis in revealing the author's individualizing identificational features is proved, the paper also outlines the prospects for further research in the field of studying the linguistic personality of the digital age.

Key words: text, dialogical speech, written dialogical speech, Internet-based communication, messenger, authorship identification, individualizing feature, transformation of individualizing feature.

Citation. Gromova A.V. Correspondence in the Messenger: Identifying the Author by Text in the Context of the Transformation of Individualizing Features. Vestnik Volgogradskogo gosudarstvennogo universiteta. Seriya 2. Yazykoznanie [Science Journal of Volgograd State University. Linguistics], 2021, vol. 20, no. 2, pp. 87-98. (in Russian). DOI: https://doi.org/10.15688/jvolsu2.2021.2.8
\end{abstract}

\section{ПЕРЕПИСКА В МЕССЕНДЖЕРЕ: ИДЕНТИФИКАЦИЯ АВТОРА ПО ТЕКСТУ В УСЛОВИЯХ ТРАНСФОРМАЦИИ ИНДИВИДУАЛИЗИРУЮЩИХ ПРИЗНАКОВ}

\footnotetext{
Анастасия Викторовна Громова

Экспертно-криминалистический центр МВД России, г. Москва, Россия 


\section{РЕЧЕВЫЕ МЕХАНИЗМЫ И ЕДИНИЦЫ ТЕКСТОВОЙ КОММУНИКАЦИИ}

ции при учете фактора использования автором технических средств для набора текста. Представлены применяемые при производстве автороведческих экспертиз основные подходы к выделению идентификационно значимых признаков печатной речи, продуцируемой автором в ходе переписки в мессенджере. Аргументирована возможность выявления совокупности индивидуализирующих признаков по таким материалам. Показана важность исследования признаков графического и коммуникативного уровней анализа диалогических текстов, приведены примеры реализации таких признаков. Доказана целесообразность сочетания лингвистических и квантитативных методов анализа речевого материала при установлении индивидуализирующих признаков автора, намечены перспективы дальнейших исследований в области изучения языковой личности цифровой эпохи.

Ключевые слова: текст, диалогическая речь, письменная диалогическая речь, интернет-коммуникация, мессенджер, идентификация автора, индивидуализирующий признак, трансформация индивидуализирующего признака.

Цитирование. Громова А. В. Переписка в мессенджере: идентификация автора по тексту в условиях трансформации индивидуализирующих признаков // Вестник Волгоградского государственного университета. Серия 2, Языкознание. - 2021. - Т. 20, № 2. - C. 87-98. - DOI: https://doi.org/10.15688/jvolsu2.2021.2.8

\section{Введение}

Прогресс в области технологий современной коммуникации формирует качественно новые условия и возможности для продуцирования текстов и иных форм обмена информацией. Интернет-реальность обеспечивает возможность дистанционного, мобильного и, при необходимости, анонимного речевого взаимодействия. В повседневное общение прочно вошли программы для мгновенного обмена сообщениями в мессенджерах - интернетприложениях, позволяющих в режиме реального времени обмениваться приватно, в паре или в группе письменными (печатными), голосовыми сообщениями и видеопосланиями, документами, фотографиями и т. д. Порождаемые в ходе такого взаимодействия речевые произведения и их письменная фиксация демонстрируют, что дистанционная коммуникация стала более динамичной, а письменная речь приобрела черты разговорной. Границы классической дихотомии устной и письменной форм речи все более подвижны, а особенности разговорного стиля, традиционно отмечаемые в устной речи, в полной мере находят свое отражение в интернет-коммуникации.

В этой связи представляется особенно актуальным изучение языковой личности, формирующейся под влиянием глобальной цифровизации. Так, одной из проблем исследования новых форм текстовой коммуникации в формате общения посредством мессенджеров стала нейтрализация речевых особенностей автора, обусловленная приемлемым для него игнорированием граммати- ческих, орфографических, пунктуационных норм, использованием специальной лексики и иконических знаков. Однако, несмотря на тенденцию к универсализации языковых средств, общение онлайн, опосредованное мобильным устройством и функционалом мессенджеров, характеризуется появлением дополнительной группы признаков, индивидуализирующих автора, ведущего диалог в мессенджере. Данные признаки требуют обобщения и систематизации как для обеспечения полноты и всесторонности экспертного анализа, так и в целом для фундаментальных исследований в области языковой личности цифровой эпохи.

\section{Материал и методы}

В последние 10-15 лет особенностям интернет-коммуникации посвящено значительное количество научных работ. Исследователи отмечают устно-письменную природу такого речевого взаимодействия, имея в виду тенденцию к максимальному сближению письменной речи с устной разговорной. Так, Ф.О. Смирнов выделяет следующие особенности интернет-дискурса: электронный сигнал, дистантность и опосредованный характер общения, использование гипертекста, статусное равноправие участников, сочетание различных типов дискурса, вербальной и невербальной информации, специфическая компьютерная этика, динамичность самопрезентации, психологические особенности интернет-общения, высокая эмоциональная насыщенность [Смирнов, 2004]. 
А.Б. Кутузов называет в качестве специфических признаков интернет-коммуникации иллокутивность, цифровой канал передачи сигнала, дистантность, анонимность, практическую непосредственность или сетевую структуру, гипертекстуальность, мультимедийность, устнописьменный характер коммуникации [Кутузов, 2006]. В.М. Лейчик пишет о том, что развивается новая форма речи - устно-письменная [Лейчик, 2007]. Е.И. Литневская указывает на появление новых форм письменной разговорной речи, позволяющих общаться в режиме реального времени или в приближенных к нему условиях [Литневская, 2009].

В целом исследователи отмечают близость интернет-языка и разговорной речи, демонстрируя, что на лексическом уровне для языка интернет-коммуникации характерно нарушение установленных канонов письменной речи: слова теряют дефис, отдается приоритет строчным буквам, в том числе в наименованиях, исчезают знаки препинания. Широко используются эрративы (написание слов с намеренным нарушением нормы), обсценная лексика, сленг. Е.Г. Соколинская выделяет следующие лексические особенности чатов: употребление жаргонной, экспрессивно окрашенной и разговорной лексики; употребление неологизмов, аббревиатур; смешение русской и английской лексики в рамках одного высказывания, при этом частотное сохранение латинского варианта написания ( а ты когда come back?; что за траблье?); употребление фраз-действий, описания вместо эмотиконов (глядя с недоумением; радостно улыбаясь) [Соколинская, 2004, с. 144].

Значительные трансформации языковых средств в рамках интернет-общения происходят в морфологии и синтаксисе высказываний. Например, меняется соотношение частей речи. Как отмечает Е.И. Литневская, «число местоимений, как правило, превосходит число существительных. Местоимения выполняют функцию заполнителей пустот, вносят уточнения, пояснения в речь, а также замещают существительные» [Литневская, 2011 , с. 52]. Б. Тошович фиксирует появление специфических глаголов, характерных для интернет-языка: гуглить «искать информацию в Интернете при помощи Google», ульбнуть «вызвать улыбку, рассмешить, развеселить», ванговать «предсказывать, предполагать что-либо» [Тошович, 2015]. А.Б. Летучий выделяет особенности в употреблении предиката: нестандартные непереходные употребления глагола, конструкции с опущением слов компьютер, интернет в функции подлежащего и др. [Летучий, 2014, с. 162]. Е.И. Литневская указывает на использование в качестве номинаций местоимений, существительных в косвенном падеже с предлогами, конструкций со спрягаемыми формами глагола; значительно более частое употребление полной формы прилагательного по сравнению с краткой формой; использование глагольных форм в переносном употреблении и др. [Литневская, 2011].

Г.Н. Трофимова к новым реалиям языка относит письменную фиксацию устной разговорной речи, введение понятий «письменнослушающий» и «письменно-говорящий», ключевое слово-запрос, обладающее характеристиками свернутого текста, «тему» в электронном послании, элементы пиктографического письма в качестве невербальных средств веб-коммуникации и возрождение эпистолярного жанра. Исследователь отмечает, что в Интернете функционируют все стили речи, в которых наблюдаются существенное влияние разговорности, рост диалогичности и полилогичности с одновременной минимизацией избыточности, тенденция к телеграфности речи и стандартизация клишированных формул наряду с концентрацией экспрессивности и лаконичности [Трофимова, 2008].

Перечисленные особенности проявляются, в частности, при продуцировании письменной речи в приватных диалогах, реализуемых с использованием мессенджеров.

Устная и письменная речь в классическом понимании имеют принципиальные отличия, основанные на разном производстве и восприятии данных дискурсов, а также особенностях психодинамики зрения и слуха. Устная речь материализуется в виде звуковых волн, а письменная - в виде букв, фиксируемых разными средствами. В устной речи, по мнению исследователей, процесс формирования высказывания протекает параллельно с процессом мышления, в то время как письменная речь характеризуется контролем пишущего за протекающими опе- 


\section{РЕЧЕВЫЕ МЕХАНИЗМЫ И ЕДИНИЦЫ ТЕКСТОВОЙ КОММУНИКАЦИИ}

рациями и используемыми языковыми средствами (см. работы Н.И. Жинкина, А.Р. Лурии, Л.С. Выготского и др.).

Известно, что в устной речи размыты границы не только формальных синтаксических единиц (предложений), но и коммуникативных единиц (отдельных высказываний). С.В. Андреева отмечает, что «речевое и языковое существуют в органическом единстве, можно говорить о двуплановости этих единиц: в них происходит соединение (слияние) конструктивно-синтаксических (это элементы синтаксического уровня языка) и коммуникативнофункциональных (это компоненты коммуникативного уровня речи) характеристик» [Андреева, 2006, с. 34].

С.В. Андреева также указывает на отличие не только устной и письменной форм речи, но и устной спонтанной и устной продумываемой речи. С опорой на достижения в области психолингвистики, связанные с идеями Н.И. Жинкина, А.Р. Лурии, Л.С. Выготского и др., исследователь выделяет следующие особенности реализации разных форм речи: в письменной речи речепорождение начинается со структурной схемы как знака типовой пропозиции (с последующими стадиями контроля и редактирования); в продумываемой устной речи высказывание тоже исходит из структурной схемы, представляющей собой инвариантную модель предложения или типизированный разговорный вариант модели предложения, при этом невозможно редактирование сказанного без его произнесения (отсюда перестройки, повторы и т. п.); в спонтанной речи высказывание может исходить как из структурной схемы с возможной ее модификацией, так и из экстралингвистического контекста (рефлекторные речевые проявления, несоотносимые с моделью предложения, синтаксически и коммуникативно нечленимые разговорные клише и т. п.) [Андреева, 2006].

Указанные характеристики, а также в целом диалогичность речи определяют многие особенности не только устной речи, но и письменной (печатной) речи, продуцируемой с использованием мессенджеров. Диалогическое общение всегда протекает в определенной коммуникативной ситуации, которая представляет собой базовый экстралингвистический фактор (см. работы Л.П. Якубинского, Т.Г. Ви- нокур, М.М. Бахтина и др.). Понятие «ситуация» включает все известные собеседникам обстоятельства, речевые и неречевые условия. Для общения важны предметы, обстановка, количество участников, третьи лица, пространство и время, в которых происходит коммуникация. К.А. Долинин относит эти компоненты к предметно-событийному фону, включая в него и события, происходящие вокруг. Автор отмечает, что «при дистантном общении место, а часто и время порождения сообщения адресантом и место и время восприятия сообщения адресатом не совпадают» [Долинин, 2010, с. 22].

В фокусе нашего внимания находятся дистантные диалоги в мессенджере, в которых участвуют два собеседника и сообщения передаются мгновенно. Как отмечает О.К. Голошубина, разговор в мессенджере имеет сиюминутный характер, общающиеся стремятся как можно быстрее обменяться информацией, поэтому для успешного общения скорость коммуникации является едва ли не главным условием [Голошубина, 2017, c. 63]. Вместе с тем скорость их прочтения и продуцирования ответной реплики всегда зависит от экстралингвистических условий, в которых адресат получает сообщение.

Изучению жанровых особенностей разговора в мессенджере посвящены работы Е.И. Горошко, Е.А. Земляковой, О.К. Голошубиной и др. Учеными рассматриваются характерные лексические, синтаксические и паралингвистические особенности общения в мессенджере как новом жанре интернеткоммуникации. По мнению исследователей, коммуникативная ситуация общения в мессенджере представлена разговорным дискурсом и детерминирована как фактом синхронности, так и технологическими особенностями клиентской программы, с помощью которой осуществляется коммуникация [Горошко, Землякова, 2017].

Обобщив различные точки зрения, обозначим исследуемую форму речи как диалогическую печатную (письменную) речь. В данной формулировке отражается понимание речи как продукта интеллектуальной деятельности, учитывается форма ее реализации и особенности продуцирования - использование устройства для набора текста. 
Следует отметить, что печатный диалог в мессенджере и устная речь в дистантном разговоре имеют как схожие, так и отличительные характеристики. Например, порождение высказываний, как правило, осуществляется без предварительной подготовки, однако в мессенджере результат обмена репликами имеет визуальное представление. Это позволяет, в отличие от устного разговора, перечитать текст, вернуться к теме, дополнить, разъяснить, продублировать сообщение, процитировать его и т. д. Интонации, жесты, мимика заменяются графическими средствами. При этом их графические эквиваленты поддаются обдумыванию, то есть осознанному отбору средств, с помощью которых автор демонстрирует собеседнику те или иные эмоциональные реакции.

Значимую функцию коммуникативного регулятора в ходе переписки в мессенджере могут выполнять такие его опции, как выбор коммуникантами мгновенного или отсроченного ответа, возможность редактирования сообщения до нажатия кнопки «отправка», удаления сообщений у себя и у собеседника. Кроме того, важным фактором, влияющим на ход коммуникации, как показано лингвистами, является возможность видеть на экране, прочитано ли сообщение получателем, печатает ли он в данный момент ответ, находится ли «в сети», данные о последнем посещении (см., например: [Назарова, Громова, 2019]).

Таким образом, диалог в мессенджере сочетает в себе признаки разговорной устной и письменной речи, а также признаки электронной коммуникации (использование опций устройства и программы для набора текста), которые находятся в отношениях взаимного влияния. Сложность обнаружения индивидуализирующих признаков пишущего обусловлена увеличением количества групповых признаков, характерных в целом для языка интернет-коммуникации. При этом в условиях трансформации черт языковой личности под влиянием цифровизации наблюдается появление новых признаков, детерминированных авторским выбором языковых и неязыковых средств в процессе диалога в мессенджере. Такой выбор, с одной стороны, опирается на представления автора о типовых особенностях и допустимости использования тех или иных языковых средств в онлайн-коммуникации, а с другой - отражает индивидуальные предпочтения личности в выборе функциональных инструментов мессенджера, особенности коммуникативного взаимодействия с собеседником при учете экстралингвистических факторов.

Исследование, результаты которого представлены в статье, опирается на обобщение практики производства автороведческих экспертиз по материалам приватных переписок в мессенджере («WhatsApp», «Vipol», «Viber», «Сигнал»). В качестве эмпирического материала использовались переписки более 50 разных авторов в объеме от 150 до 500 высказываний, реализованных ими в диалогическом взаимодействии.

\section{Результаты и обсуждение}

Диалогическое общение в мессенджерах активно используется в преступных целях, например при незаконном обороте наркотических средств, вовлечении в экстремистскую, террористическую деятельность, осуществлении развратных действий в отношении малолетних, склонении к самоубийству, мошеннических действиях. Переписки в мессенджеpax все чаще используются в качестве доказательств при расследовании преступлений различных категорий.

Для криминалистической идентификации лиц по материалам интернет-переписок может быть проведена судебная автороведческая экспертиза. Научные основания автороведческого исследования опираются на достижения филологических дисциплин в области когнитивной лингвистики, теории речевых жанров, лингвистической прагматики, коммуникативной стилистики текста, теории дискурса, лингвистической теории эмоций, семиотики, прикладной лингвистики, а также на теорию криминалистической идентификации. Автороведческое исследование базируется на представлении о тексте как об «интеллектуальном следе», продукте целенаправленной речевой деятельности индивида, что определяет возможность выявления совокупности признаков его автора.

Имеющиеся научные исследования в области интернет-жанра разговора в мессен- 


\section{РЕЧЕВЫЕ МЕХАНИЗМЫ И ЕДИНИЦЫ ТЕКСТОВОЙ КОММУНИКАЦИИ}

джере посвящены описанию общих языковых особенностей, свойственных данному формату коммуникации в целом, в то время как задачи криминалистического автороведения направлены на выделение совокупности индивидуализирующих признаков, характерных для конкретного автора. В связи с тем, что переписка в мессенджере представляет собой новый тип объекта автороведческой исследования, в целях криминалистической идентификации участников переписки по создаваемым ими текстам необходима корректировка и дополнениеперечня идентификационно значимых признаков письменной речи, приводимых в существующих методиках производства автороведческих экспертиз. Проведение таких исследований характеризуется повышенной сложностью и требует высокой лингвистической квалификации эксперта.

Обращение к проблеме идентификации личности в рамках филологической компетенции исследователя обусловлено необходимостью учитывать роль субъективного фактора в смысловой и структурной организации текста и сопряжено с пониманием языкового знака как средства фиксации когнитивной деятельности индивида. С.В. Ионова отмечает, что «установление индивидуальных черт личности по данным языка - задача, ставшая уже традиционной в лингвистике. <...>. Будучи отражением категории единичного, идентификация предполагает поиск специфики языковой личности, которая проявляется как относительно обособленная, дискретная, отграниченная от других, обладающая спецификой, составляющей ее неповторимую определенность» [Ионова, 2017, с. 79]. С точки зрения криминалистики идентифицировать объект значит установить его тождественность с самим собой, используя оставленные им отображения. В основе идентификации лежит метод сравнения двух или нескольких объектов для установления того, что их объединяет или различает. Под идентификацией в криминалистике понимают сравнительное исследование материальных объектов и их отображений с целью разрешения вопроса о тождестве и получения судебных доказательств.

Экспертная идентификация применяется в тех случаях, когда для исследования свойств отождествляемых объектов и их ото- бражений требуются специальные знания в области какой-либо науки и владение методикой идентификации определенных видов объектов. При необходимости исследования письменной речи, зафиксированной в печатной форме, проводится судебная автороведческая экспертиза.

В криминалистической теории идентификации признаки автора текста традиционно разделяются на общие и частные. С.М. Вул под общими признаками предлагает понимать уровень владения определенными нормами литературного языка, а именно: лексикофразеологическими, синтаксическими, стилистическими, орфографическими, пунктуационными. Автор выделяет общие и частные признаки формально-логических навыков и интеллектуальные навыки личности (характер восприятия действительности, акцентуации, аргументации, наличие и характер оценки описываемых объектов). Общие признаки выделяются путем оценки языковых средств на основе критерия «правильно - неправильно». При этом различается высокая, средняя и низкая степень развития языковых навыков. Частные языковые признаки отражаются в устойчивых языковых нарушениях, устойчивом использовании определенных языковых средств и в устойчивых соотношениях языковых средств, используемых индивидом в типичных речевых ситуациях [Вул, 1977]. Предложенные ученым методические подходы нашли развитие в комплексной методике производства автороведческих экспертиз, подготовленной в 2007 г. ЭКЦ МВД России и ИК ЦСТ ФСБ России. Эмпирический материал, на котором вырабатывались методические подходы, представлял собой преимущественно рукописные тексты или тексты, набранные на печатной машинке. Существенные преобразования, вызванные повсеместным распространением интернет-коммуникации и изменением способов создания и обмена текстами, обусловили дальнейшее совершенствование научно-методического обеспечения. На современном этапе развития автороведческой экспертизы решение диагностических и идентификационных задач осуществляется в соответствии с обновленными методическими рекомендациями (см. подробно: [Диагностика..., 2014; Анализ компонентов ситуации..., 2018]), 
в которых учтены особенности текстов, создаваемых с использованием современных технических средств. В них реализуется комплексный методический подход, названный С.М. Вулом системно-структурным, что подразумевает анализ как языковых, так и неязыковых (интеллектуальных, технических) структур в их взаимообусловленности.

При идентификации автора по тексту частные признаки письменной речи выявляются посредством анализа единиц лексического, синтаксического, морфологического уровней языка, а также рассмотрения коммуникативных особенностей взаимодействия с собеседником, составления карты ошибок. Исследование материалов переписки в мессенджерах проводится с учетом особенностей выбора автором языковых средств в условиях интернет-коммуникации, а также используемого при создании сообщений интерфейса мессенджера и типа электронного устройства (размер экрана, его состояние, клавиатура и др.). Кроме того, поуровневый лингвистический анализ дополняется исследованием комплекса признаков графического уровня. Так, значимую группу признаков, индивидуализирующих автора, составляют предпочитаемые им в переписке невербальные средства - смайлы, эмодзи, гифки, спектр используемых знаков клавиатуры, их разнообразие и частотность.

Особенностям семантики и функционирования иконических знаков в современной электронной коммуникации посвящено большое количество научных работ (см., например: [Пигина, 2013; Цыбина, Лисицына, Брашован, 2016]). Первичное назначение эмотиконов - передача эмоционального компонента коммуникации. Однако их функции активно расширяются. На сегодняшний день они применяются также для выражения различных предметных значений, а также в фатической функции. Ю.В. Крылов обращает внимание на то, что использование определенных пиктограмм эмодзи может быть рассмотрено как индивидуальный элемент языковой картины мира, а анализ окказиональной семантики эмодзи - как способ описания языковой личности: «эти пиктограммы так же, как и классические смайлики, помогают выразить эмоции в виртуальном диалоге, но, без сомне- ния, они получили дополнительную функциональную нагрузку... большинство пиктограмм клавиатуры эмодзи не соотносимы ни с какими эмоциями, а символизируют тот или иной объект действительности без его оценки. Многие эмодзи функционально экономят время и силы: вставить картинку автомобиля быстрее, чем набирать на виртуальной клавиатуре соответствующее слово. А некоторая вариативность в рисунках авто создает элемент творчества и самовыражения в процессе диалога» [Крылов, 2017, с. 52].

С нашей точки зрения, к графическому уровню анализа диалогической письменной (печатной) речи относится выявление авторских особенностей, проявляющихся:

- в использовании знаков пунктуации (например, ненормативное использование запятой как показателя смыслового членения высказывания; пропуск знаков препинания перед текстовыми эмотиконами; использование восклицательного знака как графического средства актуализации высказывания или выражения эмоций: Tы опять решил забить на самое Важное!; Ты ничего не сделал!!! и др.);

- постановке пробелов (например, тенденция к пропуску пробела перед эмотиконами; написание меры веса и обозначаемого им вещества без пробела: Вот так задание твое будет еще просто один адрес 5гАмф; Да там будет 3 адреса по 52 и др.);

- использовании разных способов обозначения числа, количества, порядка объектов (например, числительных: Т.к. два разные человека, не смогли сегодня поднять клады; Уже второй год пошел; цифр: У меня дочка 6 лет; Уже года 3, как разошлись; ЗП получает каждое 1 число), при этом время обозначается цифрами: до 13:00; после 13.00;

- использовании заглавных букв при оформлении текста (например, вариативное использование заглавной и строчной буквы при написании ответного сообщения; «неорфографическое» использование заглавных букв как средства актуализации высказывания: Я писал, что ФАС вернулся из командировки, не успевает; Всегда считаешь САМ количество веса, прежде чем заказывать ей работу и др.);

- сбоях в наборе текста (например, появление лишней буквы в слове: отпишщешь; 


\section{РЕЧЕВЫЕ МЕХАНИЗМЫ И ЕДИНИЦЫ ТЕКСТОВОЙ КОММУНИКАЦИИ}

поднимиштб; замена буквы в слове: теюе; бужет; недеою; сколькт; тогжа и др.);

- использовании небуквенных символов для выражения эмоций (например, употребление сочетания знаков )) в конце высказывания: Давай жду малышка )); Хорошо отдохнуть )); Вот у меня есть для тебя подарок));

- структурировании (членении) текста (например, сегментация реплик, их частота, среднее количество знаков в репликах и др.).

Совокупность признаков графического уровня анализа текста обладает высоким потенциалом идентификационной значимости, отражая деятельностную ситуацию его создания в процессе переписки в мессенджере (графический уровень сопоставим по значимости с фонетическим уровнем при идентификации лиц по голосу и речи). Выбор автором совокупности тех или иных средств для передачи смысла высказывания с учетом канала коммуникации, характеристик собеседника, предметно-событийного фона всегда индивидуализирует его.

Реализуя системно-структурный подход, эксперт отмечает употребление определенного языкового знака (сочетаний знаков) в соотнесении с речевым контекстом, коммуникативной ситуацией в целом. Общий признак, рассматриваемый применительно к конкретной речевой задаче, изучается в его частном проявлении как репрезентация определенной характеристики автора. Т.Г. Винокур отмечает, что «говорящий совершает вербальный отбор в жестких условиях преодоления альтернативы. Акт предпочтения одного языкового средства другому есть и сам говорящий, "образ автора" данного высказывания. ...Выбрать речевое средство - значит "както отнестись" и к речи, и к выраженной ею реальности» [Винокур, 2007, с. 18]. Например, при общем признаке «наличие ошибок набора (опечаток)» могут отмечаться различающиеся частные признаки, в том числе «опечатки в виде нарушения в очередности написания определенных букв», «опечатки в виде замены буквы на букву, находящуюся на клавиатуре рядом с заменяемой», «опечатки в виде пропуска буквы» и т. п.

В условиях продуцирования автором речи в формате диалогического взаимодействия особое внимание уделяется рассмотрению признаков, характеризующих его коммуникативное взаимодействие с собеседником: характер и средства выражения оценки и/или эмоций, применяемых средств воздействия, выражения субъективной модальности (например, использование оценочной лексемы красава в отношении собеседника и его действий: - бос я тут / тока пришел работал // - как дела твои братан / красава; использование речевых средств, апеллирующих к разуму, логике: старайся вообще не повторять братан / сейчас оч опастно; ну братан сам подумай / не дай бог кто спалит / они же сольют; вот разбераюсь / по этому и говорю в старые места не ложи / и не вози в салоне); особенности выбора средств для актуализации сообщаемого, взаимодействия с собеседником (например, частотное употребление слов бро, братан при обращении к собеседнику; использование контактоустанавливающих слов смотри, сльлшь / слушай в начале высказывания: смотри / потом как получишь / сразу мне пиши; сльшь / тебе зи дали?; слушай / а ты не вкурсе / он в химии шарит ? и др.).

Кроме обозначенных уровней автороведческого исследования, важным является извлечение и анализ количественных параметров текста. В ЭКЦ МВД России ведется научная работа, в ходе которой проводятся эксперименты, направленные на оценку возможности использования квантитативных методов в качестве дополняющих иные методы лингвистического анализа. На потенциал использования данных методов при идентификации автора обращается внимание в статье «Компьютерные технологии в судебной автороведческой экспертизе: проблемы и перспективы использования» [Литвинова, Громова, 2020]. Применение современного инструментария способствует повышению наглядности и объективизации данных, полученных при лингвистическом анализе иными методами.

Отметим, что при проведении экспертного анализа признаков речи автора эффективны также методы диагностического исследования в целях определения гендера, возраста, индивидуально-личностных и иных характеристик автора, а также оценки однородности авторских признаков, исключения при- 
менения алгоритмов автоматизированной генерации текстов. Диагностика характеристик автора может выступать как самостоятельная экспертная задача и как этап проведения идентификации. В связи со спецификой переписок в мессенджере представляется актуальным изучение гендерных особенностей языковой личности, проявляющихся в формате быстрого обмена личными сообщениями (выбор языковых и неязыковых средств, обусловленный гендером адресанта и адресата; фактор влияния собеседников на признаки речи друг друга).

Решение задачи идентификации автора по текстам переписки в мессенджерах сопряжено с рядом трудностей, обусловленных наблюдаемым изменением признаков пишущего в эпоху цифровой коммуникации. Характеристики, предлагаемые в имеющихся методиках производства автороведческих экспертиз, во многом неприменимы к диалогической печатной речи. В данной статье предложены подходы к выделению индивидуализирующих признаков речи, реализованной автором в ситуации обмена сообщениями в мессенджере.

\section{Заключение}

Современное состояние филологической науки и накопленная практика прикладных исследований позволяют глубоко и разноаспектно изучать такой сложный объект автороведческой экспертизы, как текст переписки в мессенджере.

Анализ диалогической письменной (печатной) речи должен основываться на применении комплексного, системно-структурного подхода, объединяющего как «качественные», так и «количественные» методы анализа. Сoвершенствование методики автороведческого исследования текста за счет дополнения лингвистических методов анализом количественных параметров (и выработка критериев для их интерпретации) является актуальной задачей.

В условиях трансформации признаков цифровой языковой личности в формате обмена сообщениями посредством мессенджеров также представляет интерес проведение фундаментальных исследований в области определения гендерных, возрастных, индивиду- ально-личностных особенностей участников переписки.

К перспективам работы относится продолжение практикоориентированных исследований, в том числе на основе формируемого корпуса текстов диалогической переписки, подготовка методических рекомендаций для производства автороведческих экспертиз в целях идентификации автора по материалам текстов, создаваемых в ходе переписки в мессенджерах.

\section{СПИСОК ЛИТЕРАТУРЫ}

Анализ компонентов ситуации создания письменного и устного (имеющего признаки подготовленности) текстов, 2018 : метод. рекомендации /Т. В. Назарова [и др.]. М. : ЭКЦМВД России. 72 с.

Андреева С. В., 2006. Речевые единицы устной речи : Система, зоны употребления, функции / под ред. О. Б. Сиротининой. М. : URSS : КомКнига. 192 c.

Винокур Т. Г., 2007. Говорящий и слушающий: варианты речевого поведения. M. : URSS. 172 c.

Вул С. М., 1977. Теоретические и методические вопросы криминалистического исследования письменной речи : метод. пособие. М. : ВНИИСЭ МЮ СССР. 109 с.

Голошубина О. К., 2017. Комплексное моделирование речевого жанра «разговор в мессенджеpe» : дис. ... канд. филол. наук. Омск. 175 с.

Горошко Е. И., Землякова Е. А., 2017. Полиформатный мессенджер как жанр 2.0 (на примере мессенджера мгновенных сообщений Telegram) // Жанры речи. № 1 (15). C. 97-100. DOI: https:// 10.185500/2311-0740-2017-1-15-92-100.

Диагностика половозрастных и индивидуальноличностных характеристик автора нерукописного текста, 2014 : метод. рекомендации / Т. В. Назарова [и др.]. М. : ЭКЦ МВД России. $112 \mathrm{c}$.

Долинин К. А., 2010. Интерпретация текста : Французский язык. М. : Просвещение. 304 с.

Ионова С. В., 2017. Идентификация и диагностика личности в лингвистике: поиск единичного и особенного // Язык и мышление : Психологические и лингвистические аспекты : материалы XVII Междунар. науч. конф. (Орехово-Зуево, 17-19 мая 2017 г.). Орехово-Зуево : Гос. гуманит.-технол. ун-т. С. 79-81.

Крылов Ю. В., 2017. Семантика эмодзи в виртуальном диалоге // Вестник Омского государственного педагогического университета. Гуманитарные исследования. № 2 (15). С. 50-52. 


\section{РЕЧЕВЫЕ МЕХАНИЗМЫ И ЕДИНИЦЫ ТЕКСТОВОЙ КОММУНИКАЦИИ}

Кутузов А. Б., 2006. Модель функционирования терминологического сленгизма в дискурсе сетевых форумов : автореф. дис. ... канд. филол. наук. Тюмень. $21 \mathrm{c.}$

Лейчик В. М., 2007. Преподавание основ культуры речи в свете новейших тенденций в развитии русского языка // Вестник Российского университета дружбы народов. Серия «Русский и иностранные языки и методика их преподавания». № 2. С. 7-12.

Летучий А. Б., 2014. Особенности аргументной структуры русских глаголов в «компьютерных» контекстах // Современный русский язык в интернете / отв. ред. Я. Э. Ахапкина, Е. В. Рахилина. М. : Яз. слав. культуры. С. 153-168.

Литвинова Т. А., Громова А. В., 2020. Компьютерные технологии в судебной автороведческой экспертизе: проблемы и перспективы использования // Вестник Волгоградского государственного университета. Серия 2, Языкознание. Т. 19, № 1. С. 77-88. DOI: https://doi.org/ 10.15688/jvolsu2.2020.1.7.

Литневская Е. И., 2009. О некоторых особенностях письменной разговорной речи // Русский язык и литература: проблемы изучения и преподавания : сб. науч. тр. Киев : УАПРЯЛ. С. 197-201.

Литневская Е. И., 2011. Письменные формы разговорной речи (к постановке проблемы). М. : МАКС Пресс. 304 с.

Назарова Т. В., Громова А. В., 2019. Опыт производства автороведческих экспертиз по материалам переписок в мессенджерах // Экспертная практика. № 86. С. 14-18.

Пигина Е. С., 2013. Смайлик как элемент эмоционального воздействия в организации общения в сети Интернет // Филологические науки. Вопросы теории и практики. № 11, ч. 2. C. $144-146$.

Смирнов Ф. О., 2004. Национально-культурные особенности электронной коммуникации на английском и русском языках : автореф. дис. ... канд. филол. наук. Ярославль. 22 с.

Соколинская Е. Г., 2004. Особенности электронного дискурса и конструирование гендерной идентичности // Культура народов Причерноморья. № 49, т. 1. С. 143-145.

Тошович Б., 2015. Интернет-стилистика. М. : ФЛИНТА. $238 \mathrm{c}$.

Трофимова Г. Н., 2008. Языковой вкус интернетэпохи в России (функционирование русского языка в Интернете: концептуальносущностные доминанты). М. : Изд-во РУДН. 300 с.

Цыбина Е. Ю., Лисицына В. О., Брашован Е. А., 2016. Смайл как выражение эмоций или ин- формативный вид общения? // Международный журнал прикладных и фундаментальных исследований. № 11, ч. 4. С. 819-822.

\section{REFERENCES}

Nazarova T.V. et al., 2018. Analiz komponentov situacii sozdaniya pismennogo $i$ ustnogo (imeyushchego priznaki podgotovlennosti) tekstov: metod. rekomendacii [Analysis of the components of the situation of creating written and oral (having signs of preparedness) texts. Methodological recommendations]. Moscow, EKTs MVD Rossii. 72 p.

Andreeva S.V., 2006. Rechevye edinitsy ustnoy rechi: Sistema, zony upotrebleniya, funktsii [Speech units of oral speech: System, areas of use, functions]. Moscow, URSS Publ., KomKniga Publ. 192 p.

Vinokur T.G., 2007. Govoryashchiy i slushayushhiy: varianty rechevogo povedeniya [Speaking and listening: variants of speech behavior]. Moscow, URSS Publ. 172 p.

Vul S.M., 1977. Teoreticheskie i metodicheskie voprosy kriminalisticheskogo issledovaniya pis'mennoy rechi: metod. posobie [Theoretical and methodological issues of forensic research of written speech]. Moscow, VNIISYe MYu SSSR. 109 p.

Goloshubina O.K., 2017. Kompleksnoe modelirovanie rechevogo zhanra «razgovor v messendzhere»: dis. ... kand. filol. nauk [Complex modeling of the speech genre "conversation in messenger". Cand. philol. sci. diss.]. Omsk. 175 p.

Goroshko O.I, Zemliakova O.A. Polyformatnyy messendzher kak zhanr 2.0 (na primere messendzhera mgnovennykh soobshcheniy Telegram) [Polyformat messenger Telegram as a genre 2.0 (on the example of messenger of instantanejus report Telegram)]. Zhanry rechi, no. 1 (15), pp. 97-100. DOI: https:// 10.185500/ 2311-0740-2017-1-15-92-100.

Nazarova T.V. et al., 2014. Diagnostika polovozrastnykh $i$ individual'no-lichnostnykh kharakteristik avtora nerukopisnogo teksta: Metodicheskie rekomendatsii [Predicting gender, age and personality traits of the author of the printed text: guidelines]. Moscow, EKTs MVD Rossii. $112 \mathrm{p}$.

Dolinin K.A., 2010. Interpretaciya teksta: Francuzskiy yazyk [Interpretation of the text: French]. Moscow, Prosveshchenie Publ. 304 p.

Ionova S.V., 2017. Identifikatsiya i diagnostika lichnosti v lingvistike: poisk edinichnogo i osobennogo [Identification and diagnosis of personality in 
linguistics: the search for the singular and special]. Yazyk $i$ myshlenie: Psihologicheskie $i$ lingvisticheskie aspekty: materialy XVII Mezhdunar. nauch. konf. [Language and thinking: Psychological and linguistic aspects: materials of the XVII International Scientific Conference]. OrehovoZuevo, Gosudarstvennyy gumanitarnotekhnologicheskiyuniversitet, pp. 79-81.

Krylov Ju.V., 2017. Semantika emodzi v virtual'nom dialoge [Emodji's semantics in the virtual dialogue]. Vestnik Omskogo gosudarstvennogo pedagogicheskogo universiteta. Gumanitarnye issledovaniya, no. 2 (15), pp. 50-52.

Kutuzov A.B., 2006. Model' funktsionirovaniya terminologicheskogo slengizma $v$ diskurse setevykh forumov: avtoref. dis. ... kand. filol. nauk [Model of functioning of terminological slangism in the discourse of network forums. Cand. philol. sci. abs. diss.]. Tyumen. 21 p.

Lejchik V.M., 2007. Prepodavanie osnov kul'tury rechi v svete noveyshikh tendentsyi v razvitii russkogo yazyka [Teaching the basics of speech culture in the light of the latest trends in the development of the Russian language]. Vestnik Rossiyskogo universiteta druzhby narodov. Seriya «Russkiy $i$ inostrannye yazyki $i$ metodika ikh prepodavaniya» [Russian and foreign languages and methods of their teaching. Series "Russian and foreign languages and methods of teaching them"]. Moscow, no. 2, pp. 7-12.

Letuchij A.B., 2014. Osobennosti argumentnoy struktury russkih glagolov v «komp'yuternykh» kontekstakh» [Russian Russian Language on the Internet: Features of the argumentative structure of Russian verbs in "computer" contexts"]. Ahapkina Ya.E., Rahilina E.V., eds. Sovremennyi russkiy yazyk v internete [Modern Russian language on the Internet]. Moscow, Yazyki slavyanskoy kultury Publ., pp. 153-168.

Litvinova T.A., Gromova A.V., 2020. Komp'yuternye tehnologii v sudebnoy avtorovedcheskoy ekspertize: problemy i perspektivy ispol'zovaniya [Computer technologies in forensic author's expertise: problems and prospects of use]. Vestnik Volgogradskogo gosudarstvennogo universiteta. Seriya 2. Yazykoznanie [Science Journal of Volgograd State University. Linguistics], vol. 19, no. 1, pp. 77-88. DOI: https:/ /doi.org/10.15688/jvolsu2. 2020.1.7.

Litnevskaja E.I., 2009. O nekotorykh osobennostyakh pis'mennoy razgovornoy rechi [About some features of written colloquial speech]. Russkiy yazyk i literatura: problemy izucheniya $i$ prepodavaniya [Russian language and literature: Problems of studying and teaching]. Kyiv, UAPRYaL, pp. 197-201.

Litnevskaja E.I., 2011. Pis'mennye formy razgovornoy rechi (k postanovke problemy) [Written forms of colloquial speech (to the problem statement)]. Moscow, MAKS Press. 304 p.

Nazarova T.V., Gromova A.V., 2019. Opyt proizvodstva avtorovedcheskikh ekspertiz po materialam perepisok v messendzherakh [Experience in the production of auto-expert examinations based on the materials of correspondence in messengers]. Expert practice, no. 86, pp. 14-18.

Pigina E.S., 2013. Smaylik kak element emocional'nogo vozdeystviya $\mathrm{v}$ organizacii obshcheniya v seti Internet [Smiley face as an element of emotional impact in the organization of communication on the Internet]. Filologicheskie nauki. Voprosy teorii $i$ praktiki [Questions of theory and practice], no. 11, part 2, pp. 144-146.

Smirnov F.O., 2004. Nacional'no-kul'turnye osobennosti elektronnoy kommunikacii na angliyskom i russkom yazykakh: avtoref. dis. ... kand. filol. nauk [National and cultural features of electronic communication in English and Russian. Cand. philol. sci. abs. diss.]. Yaroslavl. $22 \mathrm{p}$.

Sokolinskaja E.G., 2004. Osobennosti elektronnogo diskursa i konstruirovanie gendernoy identichnosti [Features of electronic discourse and construction of gender identity]. Kul'tura narodov Prichernomor'ya [Culture of the peoples of the Black Sea region], no. 49, vol. 1, pp. 143-145.

Toshovich B., 2015. Internet-stilistika [Internet stylistics]. Moscow, FLINTA Publ. 238 p.

Trofimova G.N., 2008. Yazykovoy vkus internet-epokhi $v$ Rossii (funktsionirovanie russkogo yazyka $v$ Internete: conceptual'no-sushchnostnye dominanty) [Language taste of the Internet age in Russia (functioning of the Russian language on thente Irnet: conceptual and essential dominants)]. Moscow, Izd-vo RUDN. 300 p.

Tsybina E. Yu., Lisitsyna V.O., Brasovan E.A., 2016. Smayl kak vyrazhenie emociy ili informativnyi vid obshheniya? [A smile as an expression of emotions or an informative form of communication?]. Mezhdunarodnyy zhurnal prikladnykh i fundamentalnykh issledovaniy [International Journal of Applied and Fundamental Research], no. 11, part 4, pp. 819-822. 


\section{РЕЧЕВЫЕ МЕХАНИЗМЫ И ЕДИНИЦЫ ТЕКСТОВОЙ КОММУНИКАЦИИ}

\section{Information About the Author}

Anastasiya V. Gromova, Candidate of Sciences (Philology), Deputy Head of the Department of Forensic Linguistic and Authorship Examination of Spoken and Written Text, Head of the Subdepartment of Forensic Linguistic and Authorship Text Examination, Forensic Centre of the Ministry of Internal Affairs of the Russian Federation, Zoi i Aleksandra Kosmodemyanskikh St, 5, 125130 Moscow, Russia, Gromova_85@mail.ru, https://orcid.org/0000-0001-8255-5680

\section{Информация об авторах}

Анастасия Викторовна Громова, кандидат филологических наук, заместитель начальника отдела фоноскопических, лингвистических и автороведческих экспертиз, начальник отделения лингвистических и автороведческих экспертиз, Экспертно-криминалистический центр МВД России, ул. Зои и Александра Космодемьянских, 5, 125130 г. Москва, Россия, Gromova_85@mail.ru, https://orcid.org/0000-0001-8255-5680 